\title{
Actin assembly states in Dictyostelium discoideum at different stages of development and during cellular stress
}

\author{
HELLEN C. ISHIKAWA-ANKERHOLD ${ }^{1}$ and ANNETTE MÜLLER-TAUBENBERGER*,2 \\ ${ }^{1}$ Department of Internal Medicine I, and Walter Brendel Centre of Experimental Medicine, LMU Munich, Munich, Germany \\ and ${ }^{2}$ Department of Cell Biology (Anatomy III), Biomedical Center, LMU Munich, Planegg-Martinsried, Germany
}

\begin{abstract}
The actin cytoskeleton of non-muscle cells is essential for cellular structure and subcellular organization, and the dynamic regulation of actin assembly and disassembly is a prerequisite for motility. Pioneering work using Dictyostelium discoideum focused on the biochemical analysis of non-muscle actin, the identification of actin-regulating proteins and their specific functions during processes like cell migration, cytokinesis, phagocytosis, and morphogenesis. Although subsequent work in higher eukaryotes revealed that the processes regulating actin dynamics are often much more complex, results obtained by using Dictyostelium have been of fundamental importance because they have contributed significantly to our understanding of the actin cytoskeleton in higher eukaryotes. Dictyostelium is an accepted model system for studying fast moving cells, because the single cells of the organism share many similarities with cells of the immune system such as human neutrophils. Here we provide a brief overview on the milestones of research of the actin cytoskeleton taking advantage of Dictyostelium. Furthermore, we summarize how actin structures and cytoskeletal dynamics at different stages of development have been visualized, and give an overview on the current focus of research. In addition, we discuss results showing actin assembly states during phases of cellular stress and how stress-induced actin assembly states may contribute to our understanding of certain diseases.
\end{abstract}

KEY WORDS: actin-binding protein, actin dynamics, actin rod, cellular stress, cytoskeleton

\section{Introduction}

Actin is one of the most abundant and most highly conserved proteins in eukaryotic cells, and essential for a variety of cellular processes including motility, cell division, intracellular movement, growth, differentiation, and mechanic stability. To fulfil all these different functions, actin forms a variety of dynamically regulated structures in eukaryotic cells such as plasma-membrane associated cortical networks, lamellipodia, pseudopodia, filopodia, phagocytic cups, podosomes, ruffles, microvilli, Golgi- and endosome-associated actin layers, stress fibers, microfibers, and contractile bundles (Chhabra and Higgs, 2007).

The first description of an actin-like protein in Dictyostelium discoideum was published in 1972 (Woolley, 1972) only shortly after the detection of actomyosin in Acanthamoeba castellanii (Pollard et al., 1970) and Physarum polycephalum (Nachmias and Ingram, 1970). Subsequent work demonstrated quite soon that the proteins responsible for the molecular basis of muscle contraction, actin and myosin, are also present in non-muscle cells, and that actin is essential for non-muscle cell movements. Early work conducted in the lab of James Spudich concentrated on the development of purification protocols for actin from Dictyostelium (Clarke and Spudich, 1974, Clarke and Spudich, 1977, Spudich, 1974). The proof of the association of actin filaments with the plasma membrane became possible by the use of scanning and transmission electron microscopy (Clarke et al., 1975). Subsequent studies using amoebae and a variety of non-mammalian and mammalian cell lines revealed that actin is a major constituent of most cell types and is able to form microfilaments.

The development of anti-actin antibodies that could be employed in immunofluorescence studies of fixed cells opened new avenues

Abbreviations used in this paper: Arp, actin-related protein; cAMP, 3',5'-cyclic adenosine monophosphate; DAPI, 4',6-diamidino-2-phenylindole; ET, electron tomography; GFP, green fluorescent protein; PIP3, phosphatidylinositol (3,4,5)-trisphosphate; RFP, red fluorescent protein; TIRF, total internal reflection fluorescence.

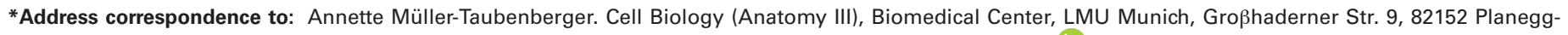
Martinsried, Germany. Tel: +49 89 2180-75873; Fax: +49 89 2180-75882. E-mail: amueller@ bmc.med.Imu.de - iD https://orcid.org/ 0000-0003-1163-9232
} 
to explore and visualize details of actin arrangements inside cells (Lazarides and Weber, 1974). This pioneering work was followed by numerous studies that described the biochemical properties of non-muscle actin. From the mid 1980s on, the focus of interest turned more and more to the identification of proteins that interact with actin and thus regulate actin functions. Work using Dictyostelium was often ground-breaking as proteins, such as for instance coronin (de Hostos et al., 1991), were either first identified or functionally analysed using the organism. Work over the years showed that Dictyostelium is a valuable model to study the principles of actin cytoskeleton dynamics and the motile behaviour of fast moving cells. In the past, a number of excellent reviews have been published discussing various aspects of these studies. Here, we give a brief overview of actin cytoskeleton research and the assembly states of actin in Dictyostelium illustrated by examples from different developmental stages, and summarize current research topics.

\section{Isolation and characterization of actin-binding pro- teins in Dictyostelium}

Actin serves both as a structural and as a force-generating protein. Inside cells, there is a dynamic equilibrium of monomeric actin (G-actin) sequestered by monomer-binding proteins like profilin, and filamentous actin (F-actin). Monomeric actin contains one nucleotide and can exist either in the ATP, ADP-Pi or ADP form. The assembly and disassembly of actin filaments is critically dependent upon the concentration of actin monomers, and the ionic conditions. Concentrations for actin assembly also vary as actin filaments themselves show a polarity and have different critical concentrations for polymerization on either end. The ATP-dependent dynamic turnover of actin has been described as 'actin-treadmilling'. In addition, the assembly of monomeric actin into filaments as well as the disassembly of filamentous actin comprises a whole arsenal of actin-binding and actin-regulatory proteins with different functionalities (Pollard and Borisy, 2003). In the past three decades, a vast number of these proteins that regulate actin assembly by their nucleating, sequestering, and crosslinking functions have been identified and characterized.

A plethora of studies analysed the functions of actin-binding proteins at the biochemical, molecular and cell biological level. The number of research papers reporting new data on the Dictyostelium actin cytoskeleton raised continuously from the late 1980s, and peaked between 1999 and 2005. Here, we give only a brief overview of the most important results of the early pioneering work with an admittedly personal view, whereas subsequent work is not considered in detail.

Among the first actin-binding proteins identified in Dictyostelium have been the actin-crosslinking proteins $\alpha$-actinin (Condeelis et al., 1984, Witke et al., 1986) and filamin (120-kDa protein, ABP120, gelation factor) (Condeelis et al., 1984, Noegel et al., 1989), and the actin-bundling protein ABP34 (Fechheimer, 1987, Fechheimer and Taylor, 1984). The characterization of the actin-binding domains in these proteins contributed to the understanding of more complex human proteins such as for instance dystrophin as well as dystrophin-related disorders (Koenig et al., 1988). Other important actin-binding proteins that were identified in the early phase of actin cytoskeleton research were the gelsolin-related actin-severing protein severin (Yamamoto et al., 1982), capping proteins (Hartmann et al., 1989), coronin (de Hostos et al., 1991), profilins (Haugwitz et al., 1991), the actin-depolymerizing factor cofilin (Aizawa et al., 1995), and talin A (Kreitmeier et al., 1995). The listing of all actin-binding proteins identified would go beyond the scope of this review.

The next phase of actin cytoskeleton research using Dictyostelium was followed by studies that led to the identification of important regulators that link signaling pathways and cytoskeletal activities. The best-investigated actin nucleator is the Arp2/3 complex, which is crucial for branch-forming of actin filaments (Insall et al., 2001, Machesky et al., 1994). Among the proteins activating the Arp2/3 complex is SCAR (suppressor of cAR), which was first identified in Dictyostelium (Bear et al., 1998), and later on in many other eukaryotes. SCAR is a WASP (Wiskott-Aldrich syndrome protein)-family protein, and subsequent work has shown that it is crucial for the activation of actin nucleation by the Arp2/3 complex (Machesky et al., 1999). The WASP family can be divided into different subfamilies: WASPs, SCAR/WAVEs, and WASH, all activating the Arp2/3 complex (Veltman and Insall, 2010). The SCAR/WAVE complex is composed of five proteins (Pir121/Sra1, Nap1, SCAR/WAVE1-3, Abi1-3, and HSPC300) (Pollitt and Insall, 2009), and activated by Rac to regulate the actin nucleating activity of the Arp2/3 complex. Another important class of actin nucleators are the formins comprising ten different and functional distinct proteins in Dictyostelium (Litschko et al., 2019, Rivero et al., 2005, Schirenbeck et al., 2005).

Only few actin-binding proteins turned out to be specific for Dictyostelium, like the membrane-associated hisactophilins (Scheel et al., 1989), or much less widely distributed like the actin-bundling cortexillins (Faix et al., 1996).

Parallel to the identification and biochemical characterization, the newly identified actin-binding proteins were analysed functionally. It became more and more obvious that actin-binding proteins are effectors of signaling cascades and serve as coordinators of cellular functions, and thus research focused increasingly on proteins involved in signaling to the actin cytoskeleton. Technical advances enabled the generation of gene replacement mutants in Dictyostelium within a few weeks (Noegel and Schleicher, 2000). The analysis of knockout phenotypes was usually complemented by localization studies of the cytoskeletal protein in question. Improvements of immunofluorescence techniques, and even more importantly the development of the GFP-technology enabled researchers to follow the distribution of cytoskeletal proteins in live cells (Gerisch and Müller-Taubenberger, 2003).

The first complete overview on the repertoire of actin and actin-binding proteins in $D$. discoideum became available after sequencing of the genome (Eichinger et al., 2005). A more detailed analysis of the Dictyostelium actinome revealed 25 actins and actin-related proteins encoded by 41 genes that were identified according to their actin sequence profile (Joseph et al., 2008). 17 conventional actins can be distinguished that share high homologies to conventional actin, but are different in their protein sequences. The conventional actins encoded by the Act8-group share identical amino acid sequences, but are encoded by 17 distinct genes. More than $95 \%$ of the $D$. discoideum actin is encoded by genes of the Act8-group. Eight members of the actinome are conserved actin-related proteins. 

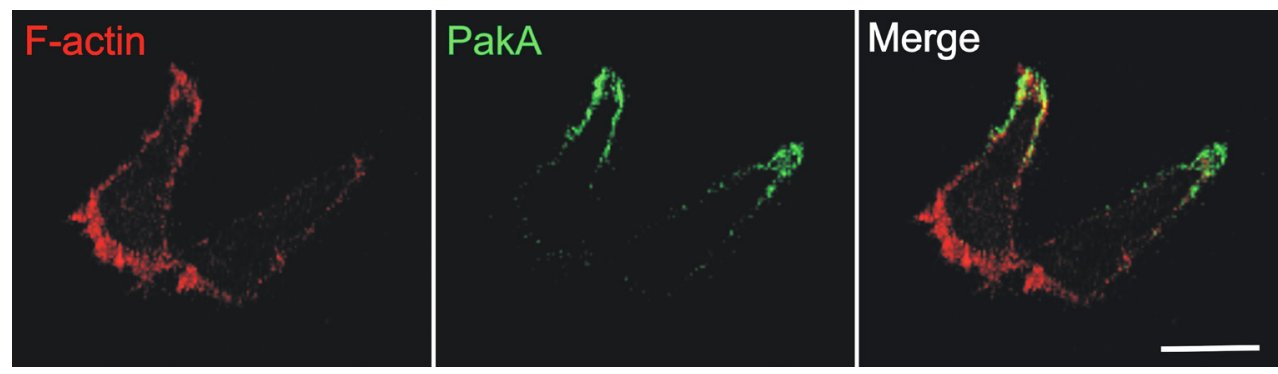

Fig. 1. Establishment of polarity during early aggregation. During directed migration, F-actin labeled by mRFP-LimEA (red) is continuouslypolymerized at the leading edge. The p21-related kinase pakA (Müller-Taubenberger et al., 2002), visualized by expression of GFPpakA (green), re-distributes to the rear of the cell where it regulates myosin-II. Images were recorded using a confocal microscope (Zeiss LSM 510). Scale bar, $10 \mu \mathrm{m}$.

\section{Dictyostelium - a model for fast migrating cells}

Chemotaxis is the guided movement of cells in chemical gradients, and constitutes an evolutionarily old mechanism. $D$. discoideum amoebae find their bacterial prey by chemotaxis towards compounds released by the bacteria. When food becomes rare, Dictyostelium cells differentiate and aggregate to form a multicellular organism. At this stage of the developmental cycle, cAMP released by starving $D$. discoideum cells themselves, serves as the chemotactic signal for directed migration towards an aggregation center (Gerisch, 1982, Konijn et al., 1969). These findings formed the basis for using $D$. discoideum for detailed studies of signaling pathways linked to chemoattractant receptors (Manahan et al., 2004).

Since Dictyostelium shares many characteristics with human neutrophils, it is utilized as an easily accessible model to study the principles of directed migration (Artemenko et al., 2014, Devreotes and Zigmond, 1988). Actin and its dynamic regulation are essential for all mechanisms underlying these changes and are critically involved in the establishment of polarity. Since the main prototypes of actin-binding proteins and their regulatory elements are present, results obtained with Dictyostelium have been exploited to understand the motile behaviour of immune cells (Insall, 2013, Kay et al., 2008). Furthermore, Dictyostelium has been used as a host for cell response studies upon infections with diverse pathogenic microorganisms like Pseudomonas aeruginosa, Cryptococcus neoformans, Mycobacterium spp., or Legionella pneumophila (Dunn et al., 2017). For these reasons,
Dictyostelium also became a valuable model system for biomedical research (Frej et al., 2017, Müller-Taubenberger et al., 2013).

Directional cell migration and the establishment of polarity play an important role in immune responses, wound healing, defense mechanisms and development. These processes require a complex cellular behavior that results from coordinated changes in the cytoskeleton and the controlled formation and dispersal of cell-substrate adhesion sites. It is without question that the actin system provides the driving force at the cell front, and other proteins are responsible for contraction at the rear as for instance non-muscle myosin-II. Many studies have dealt with these processes and have explored the mechanisms that underlie chemoattractant signaling (see Pal et al., this issue) and the establishment of polarity (shown in Fig. 1).

\section{Visualization of actin in Dictyostelium cells}

Until the mid-1990s, visualization of actin and actin-binding proteins was only possible either by immunofluorescence labeling combined with fluorescence microscopy or by electron microscopy employing fixed specimen. The range of methods has been greatly expanded by the availability of the GFP-technology applied to actin (Westphal et al., 1997) and actin-associated proteins (Gerisch and Müller-Taubenberger, 2003). Dictyostelium served as 'pioneer' to test fluorescently labeled probes for the analysis of live-cell dynamics in particular in studies exploring the mechanisms of cytoskeletal rearrangements. One of the first proteins that was labeled by GFP and analyzed in vivo was
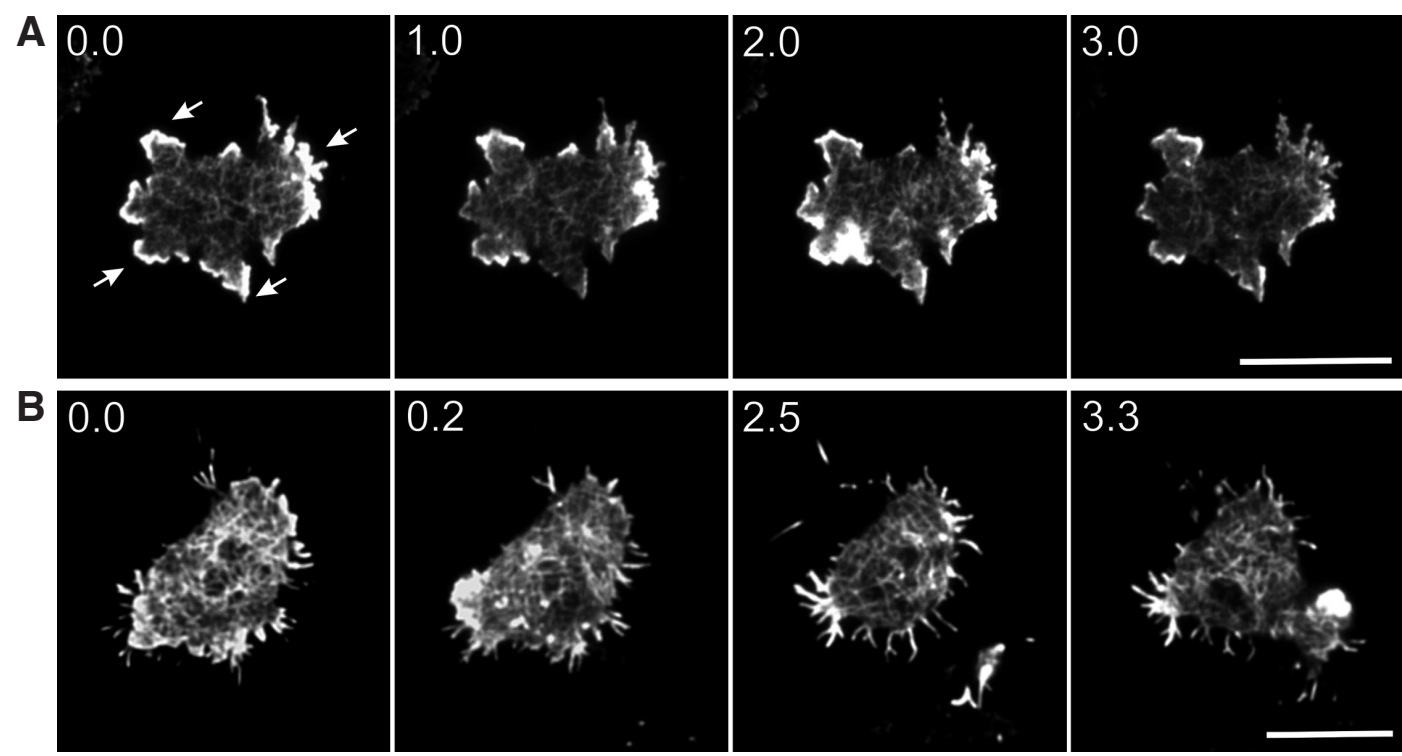

Fig. 2. Actin at the cortex and the substrate-attached surface of D. discoideum. TIRF microscopy images show patterns visualized by GFP-LimEA at the substrateattached surface of Dictyostelium wild-type cells. A rapidly restructured network of single or bundled actin filaments provides a scaffold for the assembly of differentiated actin complexes: stationary foci with a lifetime of 7-10 seconds, and traveling waves. Two representative examples of time series are shown. (A) Actin assembly observed at the cell cortex (arrows), and (B) the arrangement of actin assemblies close to the substratum. The figures correspond to Supplementary Movies $1 A, B$. The numbers in the panels indicate time in seconds. Scale bars, $10 \mu \mathrm{m}$. 


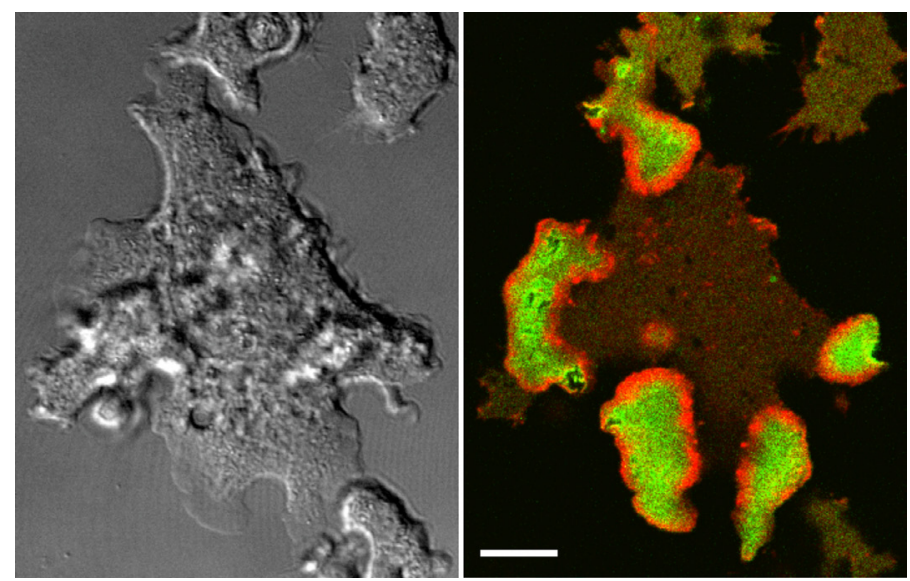

Fig. 3. Actin wave formation on the cytoplasmic face to the substrateattached membrane of a large cell of $\boldsymbol{D}$. discoideum. Actin assemblies similar to those driving the protrusion of a leading edge are freely formed at the inner face of the plasma membrane at the base of the cells. These primordia represent an activated state of the actin system that enables the cells to respond within seconds to local stimuli. The cell was produced by electric-pulse induced fusion of single cells (Lange et al., 2016), and expressed mRFP-LimEA as a label for filamentous actin (red) and GFPPHcrac as a marker for PIP3 (green). The confocal image (Zeiss LSM 780) shows that actin waves subdivide the membrane into distinct domains: in PIP3-rich inner territories circumscribed by a wave, and in the external area depleted of PIP3. Bar, $10 \mu \mathrm{m}$. The dynamic view of the cell displayed in the figure is shown in Movie 2. The figure was kindly provided by Günther Gerisch and Mary Ecke (MPI for Biochemistry, Martinsried).

coronin (Maniak et al., 1995). Coronin was shown to be crucially important for phagocytosis, and later on to mediate depolymerization of filamentous actin.

Today, a whole palette of fluorescent proteins is available that
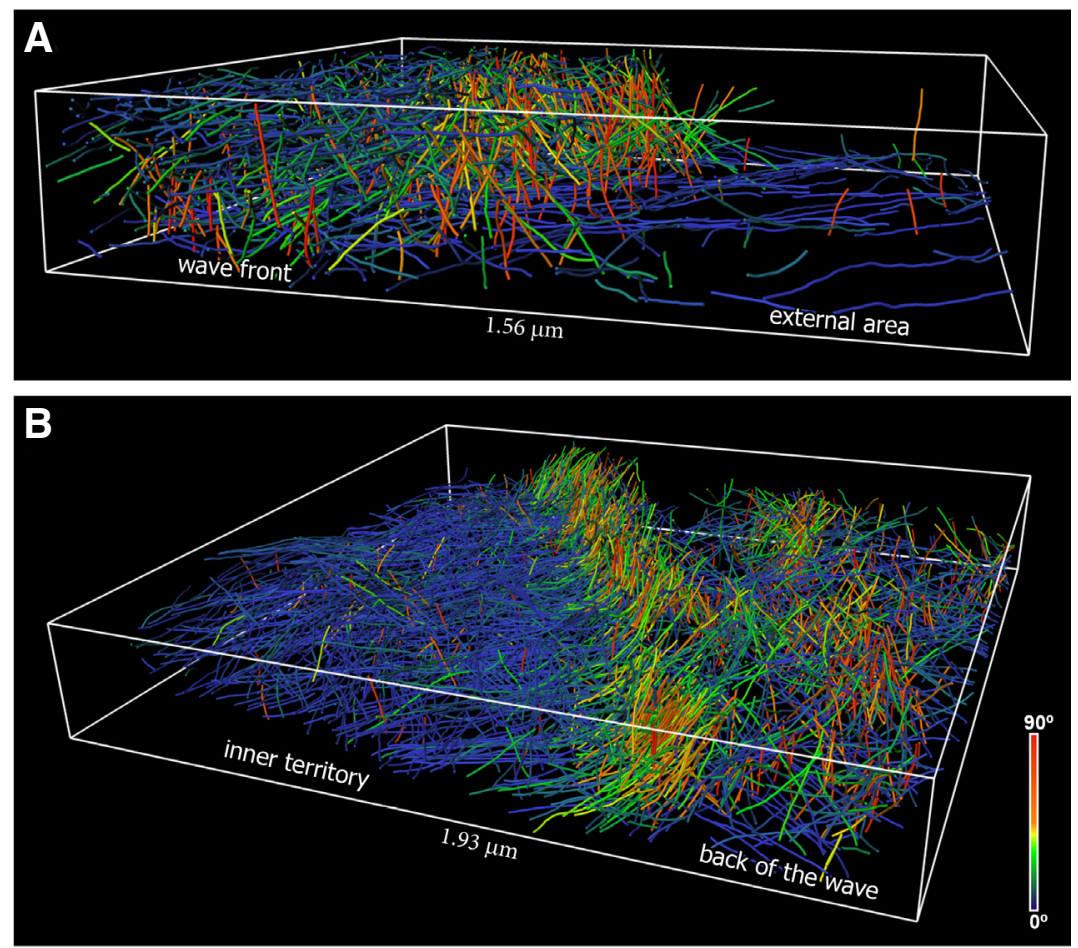

can be combined with specific probes for actin to visualize the actin filament system and cytoskeletal dynamics at high temporal and spatial resolution in live Dictyostelium cells (Müller-Taubenberger, 2006, Müller-Taubenberger and Ishikawa-Ankerhold, 2013). In addition, the improvement of microscopes and different microscopic techniques to explore cells expressing multiple fluorescently labeled markers enabled high-resolution insights into live cells (Müller-Taubenberger and Anderson, 2007).

Different protein probes tagged with fluorescent proteins (FP) have been used to visualize filamentous actin in Dictyostelium cells. Among the markers that have been used are the FP-tagged actin-binding domain of Dictyostelium filamin (ABD120). The best markers proved to be FP-tagged LimE $\Delta$ (Fischer et al., 2004) and FP-tagged Lifeact (Müller-Taubenberger and Ishikawa-Ankerhold, 2013, Riedl et al., 2008). However, different fluorescent proteins tagged to marker proteins show small variations in the labeling capacity (our own observations), and the different fusion proteins did not label all F-actin of cells to the same extent (Lemieux et al., 2014). The FP used for visualization changes the subset of $\mathrm{F}$-actin labeled by an F-actin probe, and the linker used between the FP and an actin-binding domain can similarly alter the subset of F-actin recognized in vivo (Lemieux et al., 2014).

In addition, the use of new techniques and more powerful microscopes has allowed for significant improvements in resolution and signal-to-noise ratios. Total internal reflection fluorescence (TIRF) microscopy is a fluorescence technique that selectively excites fluorescently labeled structures within an evanescent field extending only about $150 \mathrm{~nm}$ from the substrate into the substrate-near surface of the cell. In $D$. discoideum cells, the membrane-anchored actin filament network has a thickness of $100-200 \mathrm{~nm}$, and thus almost its entire structure is amenable to visualization by TIRF. Therefore, TIRF microscopy is an excellent tool to analyze the actin organization close to the substrateattached surface of Dictyostelium cells. Imaging by TIRF microscopy in combination with a marker for filamentous actin, GFP-LimE $\Delta$, enabled for the first time hitherto unresolved details of actin structures close to the substratum (Bretschneider et al., 2004) (see Fig. 2, and Supp. Movies 1 A,B). The rapidly restructured network of actin filaments provides a scaffold for the assembly of differentiated actin complexes, such as temporarily existing actin foci and traveling waves.

Another technique that has been applied to Dictyosteliumcells was cryo-electron tomography (cryo-ET). The use of cryo-ET enabled to image the network of actin filaments in unfixed and non-extracted cells and to measure the geometry of actin in its natural environment using vitrified specimens (Medalia et

Fig. 4.Architecture of $D$. discoideum actin waves revealed by cryo-electron tomography. (A,B) The images show rendering of actin filaments extracted from tomograms of actin waves (Jasnin et al., 2019). Views of the front of a wave propagating into an external area (A) and of the back of a wave leaving behind an inner territory (B). Filament orientation relative to the membrane is color-coded using the map displayed on the right in (B). A box indicates the volume occupied by the network. The figure was kindly provided by Marion Jasnin (MPI for Biochemistry, Martinsried). 

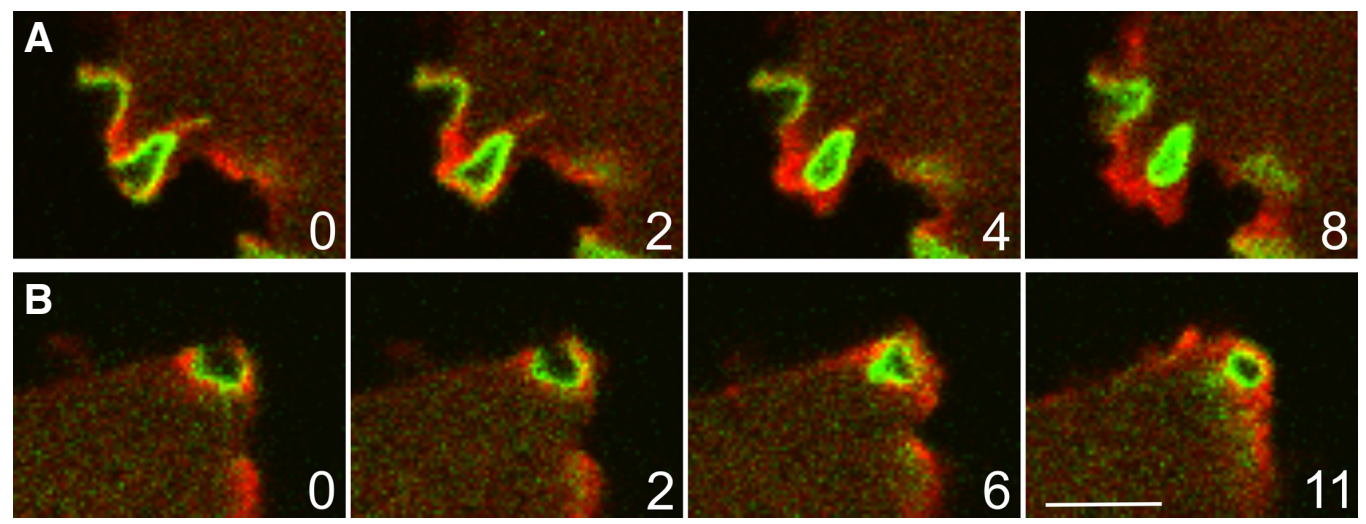

Fig. 5. Macropinocytosis. (A,B) $/ m$ ages show two sets of recordings of a large cell of D. discoideum produced by electric-pulse induced fusion undergoing macropinocytosis. The cell expressed mRFP-LimEA (red) to visualize filamentous actin, and PHcrac-sfGFP (green) as a marker for PIP3, and was recorded by confocal microscopy (Zeiss LSM 780). Time is indicated in seconds. Bar, $10 \mu \mathrm{m}$. The complete series of events can be watched in Supp. Movie 3. The figure was kindly provided by Günther Gerisch and Mary Ecke (MPI for Biochemistry, Martinsried).

al., 2002). Further improvements of cryo-ET revealed totally new and stunning views of the arrangement of actin filaments in highly dynamic filopodia of Dictyostelium amoebae (Medalia et al., 2007).

\section{Current hot topics in actin cytoskeleton research using Dictyostelium as a model}

\section{Actin waves}

Traveling actin waves are waves of polymerized actin filaments and associated proteins that propagate along the substrateattached surface (Bretschneider et al., 2009) (Fig. 3, and Supp. Movie 2). These supramolecular structures have been first described by confocal microscopy studies (Vicker, 2002), and were more clearly visualized by TIRF microscopy (Bretschneider et al., 2009, Bretschneider et al., 2004). In addition to Dictyosteliumcells, actin waves have been seen in many different motile cells such as leukocytes, fibroblasts, melanoma cells, osteosarcoma cells, keratocytes and neurons (Inagaki and Katsuno, 2017). There is increasing evidence that actin waves contribute to cellular polarization, migration, cell protrusion and intracellular transport. Actin wave propagation in Dictyostelium cells is linked to changes in membrane phosphoinositides and certain actin-associated proteins (Schroth-Diez et al., 2009), specifically to patterns of PIP3 and the PIP3-phosphatase PTEN (phosphatase tensin homolog) (Arai et al., 2010, Gerisch et al., 2012).

A recent in situ cryo-ET study has beautifully elucidated the native architecture of traveling actin waves in Dictyostelium cells (Jasnin et al., 2019) (Fig. 4), showing that actin waves comprise tent-like arrays of actin filaments within a horizontal actin meshwork. The quantitative analysis of branch orientation provides evidence that waves progress by de novoactin nucleation (Jasnin et al., 2019). This study complements earlier cryo-ET work on actin structures in cell protrusions using cryo-correlative light and electron microscopy (Jasnin et al., 2016).

\section{Amoeboid movement: pseudopod formation vs. blebbing}

In the field of migration research Dictyostelium often played a pioneering role compared to leukocytes. However, the surprising finding that integrins are not essential for the migration of neutrophils in the interstitial space (Lämmermann et al., 2008) led to the suggestion of a new concept in amoeboid movement. When lacking integrins, neutrophils switch from a pseudopod-driven mode of migration depending on actin-network expansion to a rowing-type of movement that is now known as blebbing. Blebs are rounded projections of the plasma-membrane driven by hydrostatic pressure caused by contraction of the cell cortex, which are detached from the underlying actin cortex. Interestingly enough, the formation of blebs had already been described for Dictyostelium cells (Yoshida and Soldati, 2006), but its significance as an alternative mode of migration was not immediately recognized to its full extent. Only more recent work elucidated blebbing as an alternative mechanism for Dictyostelium cells to navigate in confined environments with high mechanical resistance (Tyson et al., 2014, Zatulovskiy et al., 2014).

\section{Macropinocytosis and autophagy}

Phagocytosis, the engulfment of particles by structures formed by the plasma membrane and the underlying cortex, was for a long time the major uptake mechanism that was investigated in addition to clathrin-mediated endocytosis. This has changed recently, since it became obvious that macropinocytosis - the non-specific uptake of fluid by cells - is not only a way to take up nutrients in Dictyostelium cells (Fig. 5, and Supp. Movie 3), but can be also observed in dendritic cells and some cancer cells. Macropinocytosis seems to be an evolutionarily old mechanism for nutrition and is now intensely investigated using the Dictyostelium model (see Kay et al., this issue). Autophagy is a process related to phagocytosis, but involved in the degradation of intracellular structures. It is also based on actin cytoskeleton activities, but will not be discussed here (see Fisher and Eichinger, this issue).

\section{Actin dynamics in aggregating cells, the slug stage and fruiting bodies}

During all stages of development, the majority of filamentous actin localizes to a thin cortical area. Development in Dictyostelium is induced by the lack of nutrients, and within few hours, the cells undergo dramatic changes that affect both transcription and protein levels. One obvious change is the striking polarization of cells. The establishment of a front and rear end is accompanied by continuous polymerization and localized accumulation of actin at the front during chemotactic movement (see Fig. 1). The signaling cascades and regulators mediating polarization are detailed elsewhere in this special issue (see Pal et al.).

During aggregation, about 100,000 polarized cells move chemotactically towards an aggregation center to form streams that finally build up a mound. Cells in mounds become more tightly packed by cell contacts and surrounded by a matrix, and 
further on differentiate into prestalk and prestalk cells (Kay, 1992). In addition, a few other cell types can be distinguished, such as anterior-like cells and a type of primitive immune cells, the sentinel cells (Chen et al., 2007, Zhang et al., 2016). Mounds can elongate into a more conus-like multicellular body, a slug, which is able to migrate phototactically. Finally, by further morphogenetic movements and cell differentiation, fruiting bodies are formed consisting of vacuolized stalk cells with cellulose walls, and numerous encapsulated spores in the head.

The multicellular stages of Dictyostelium enable exploration of the principles of collective movement. However, the Dictyostelium system has been exploited much less to study collective migration than for instance the lateral line organ of zebrafish (Haas and Gilmour, 2006, Olson and Nechiporuk, 2018) or border cells of the Drosophila egg chamber (Cai et al., 2016, Cetera et al., 2014).

Signaling waves and cellular movements during the multicellular stages of Dictyostelium development have been documented by time-lapse microscopy showing signaling centers characterized by vigorous rotational cell movement (Abe et al., 1994, Dormann et al., 1996, Siegert and Weijer, 1995). cAMP has been suggested to play a role also at the later multicellular stages and have been recently revisited (Hashimura et al., 2019). Although the actin system at the late developmental stages has not been visualized in detail, it is assumed that actin dynamics plays an important role for the morphogenetic cell movements.

The tip of slugs consists of prestalk cells that eventually die and build up the stalk. Imaging of slugs that were formed by cells which express RFP-actin in combination with GFP-cofilin, shows an enrichment of both labels in the slug tip (Fig. 6A). Later on, when fruiting bodies have formed, both labels are enriched in the papilla and at the basal annulus of the spore head (Fig. $6 \mathrm{~B})$, however the meaning of this enrichment requires further investigation.

Two-photon microscopy was used to visualize actin-dynamics at the slug stage (Fig. 7A, and Supp. Movies 4 A-C). While the cells in the rear end and the middle part show collective forward migration, cells at the tip also move collectively, but in addition display a spiral wavy pattern of movement. Sentinel cells are specialized cells of the slug stage that are able to phagocytose
Fig. 7. Two-photon microscopy of $\boldsymbol{D}$. discoideum slugs. Migratory slugs derived from cells expressing GFP-filamin (green) (Roth et al., 2015) were prepared essentially as described (Darcy et al., 1994), and recorded with a multi-photon Lavision Biotech microscope using the 840-nm wavelength excitation. (A) Recording of GFPfilamin labeled slugs (green) showing a circular movement in the front tip region (indicated by the curved arrow on the left side) (left), from the middle part of a slug (middle), and from the rear end (right). (B) The slugs were pre-labeled with 4 $\mu \mathrm{g} / \mathrm{m} /$ ethidium bromide essentially as described (Chen et al., 2007) for labelling of the sentinel cells (red). Scale bars, $100 \mu \mathrm{m}$. The images in (A) correspond to Supplementary Movies 4A-C, the merged image in (B) to Supp. Movie 5.
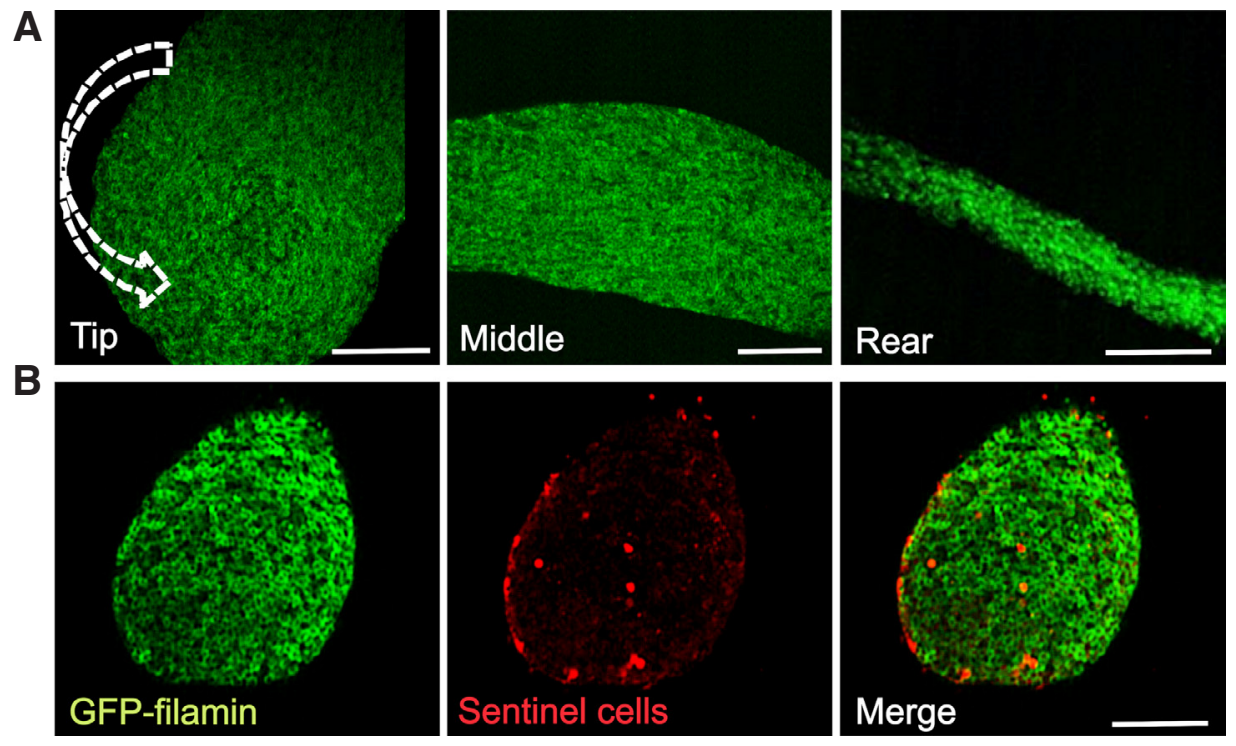
Fig. 8. Spore germination. Germination of spores generated from D. discoideum cells expressing GFP-cofilin. The hatching amoeba (indicated by the arrow) and the empty spore case (asterisk) were recorded using a confocal microscope (Zeiss LSM 510). The numbers in the upper panel indicate time in seconds. Bar, $5 \mu \mathrm{m}$. The images correspond to Supp. Movie 6.
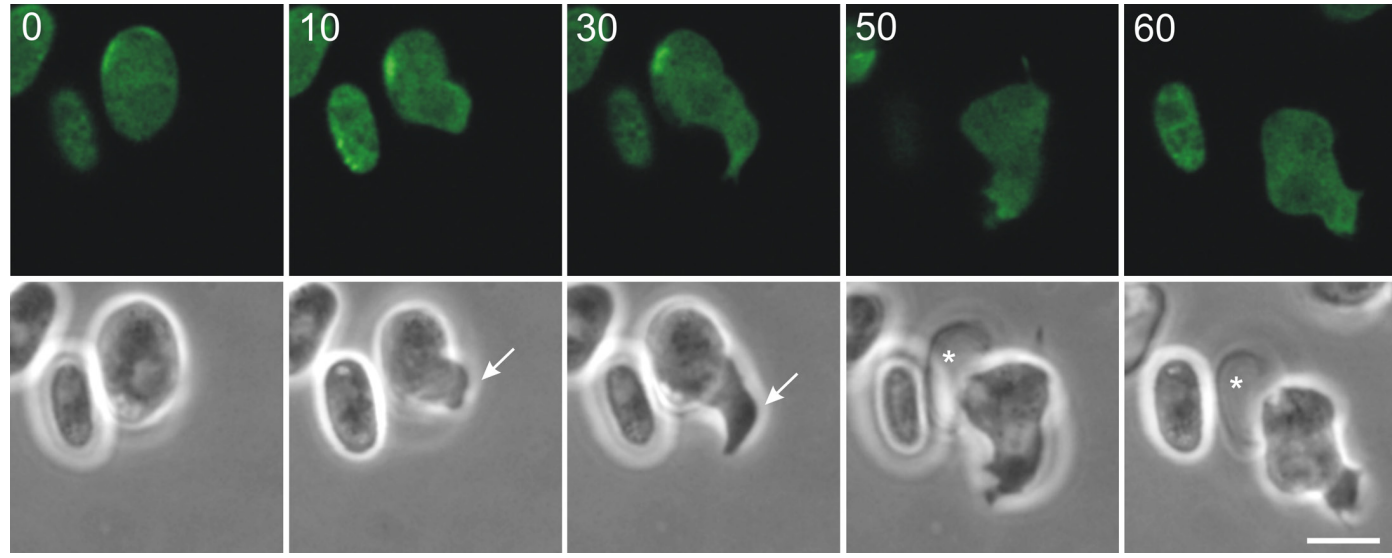

invading microbes (Chen et al., 2007). Sentinel cells move collectively together with cells in the tip (Fig. 7B, and Supp. Movie 5), and are shed at the rear end.

\section{Actin assemblies in spores and actin dynamics during spore germination}

The formation of spores enables cells to survive harsh and unfavorable environmental conditions for years or even decades. In this stage, all metabolic and cellular activities are stalled, but are rapidly reactivated after rehydration even after very long resting periods. Fully differentiated spores are highly condensed and encapsulated by a complex cellulose coat, the spore case. Inside the spores, actin is condensed into tubular structures called actin rods that are present in the cytoplasm and the nucleus (Sameshima et al., 1994, Sameshima et al., 2000). Electron microscopy of actin rods revealed a hexagonal arrangement of the actin tubules (Sameshima et al., 2001). Actin rods in spores are composed not only of actin, but also contain cofilin (Fig. 9A); other constituents have not been identified so far.

Spore germination can be divided into three sequential stages: activation of dormant spores, swelling of activated spores, and emergence of amoebae after longitudinal splitting of the spore case (Cotter and Raper, 1968). During the swelling phase, actin rods start to disassemble which can be followed by visualization of GFP-cofilin. At the time amoebae hatch, filamentous actin forms a cortical layer beneath the plasma membrane that enables the formation of pseudopods (Fig. 8, and Supp. Movie 6).
Fig. 9. Actin rods in spores, nuclei, and cytoplasm. (A) Spores generated from $D$. discoideum cells expressing GFPcofilin and RFP-actin, were fixed with methanol $-20^{\circ} \mathrm{C}$ for $15 \mathrm{~min}$, washed and stained with DAPI. (B) Nuclear rods were induced in Dictyostelium cells by treatment with 10\% DMSO for $30 \mathrm{~min}$ at room temperature. Cells were then fixed with methanol at $-20^{\circ} \mathrm{C}$ for 15 min, and washed and stained with DAPI. (C) Cytoplasmic rods were induced by treating cells expressing GFP-cofilin and mRFP-actin with $10 \mathrm{mM}$ sodium azide for $1 \mathrm{~h}$ at room temperature. Cells were fixed with methanol at $-20^{\circ} \mathrm{C}$ for $15 \mathrm{~min}$, washed and stained with DAPI. For experimental details see (Ishikawa-Ankerhold et al., 2017). All images were taken by using confocal microscopy (Zeiss LSM 880). Scale bars, $5 \mu \mathrm{m}$.
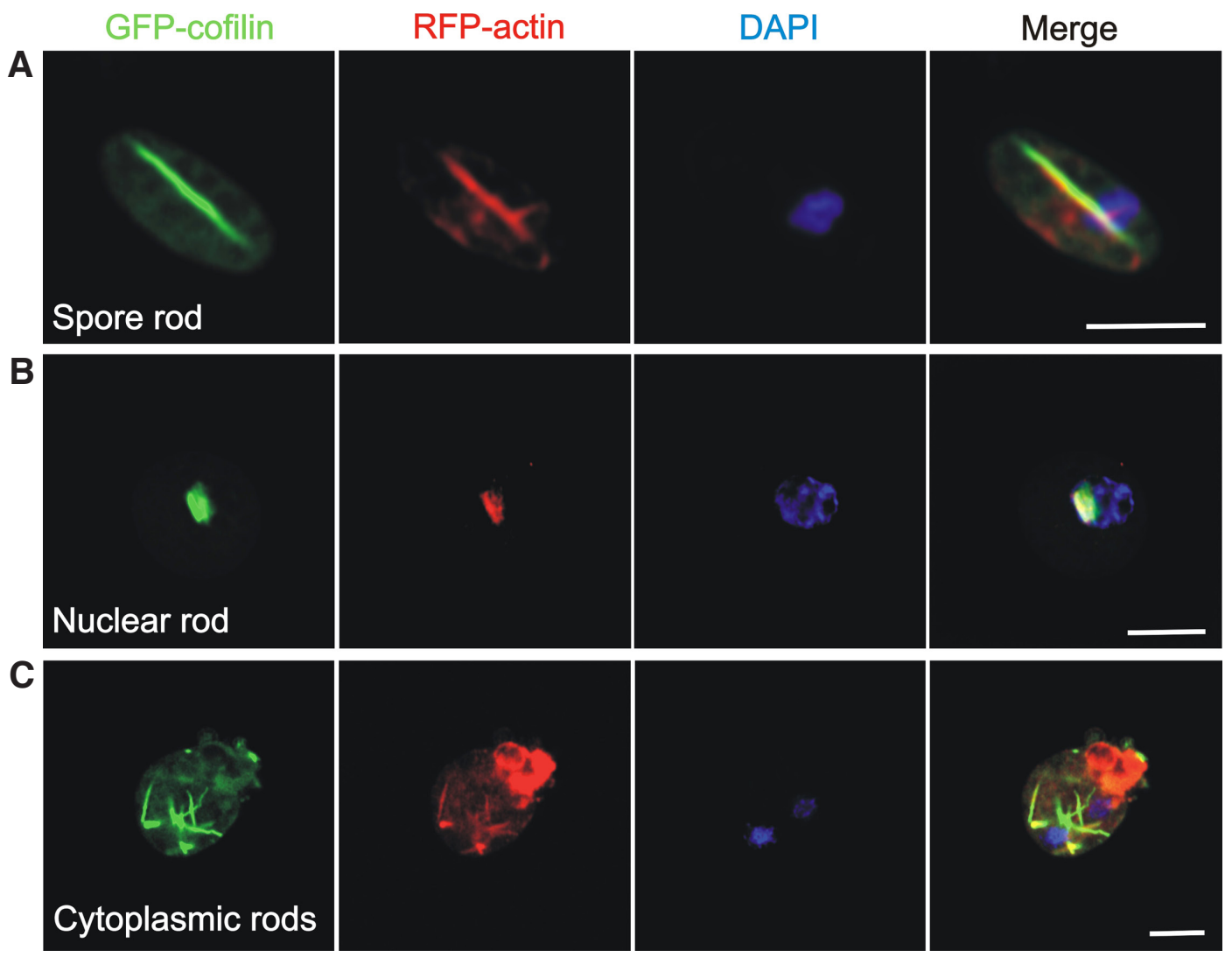
Fig. 10. The actin-related protein Arp8 localizes to the nucleus. Live Dictyostelium cells expressing GFP-Arp8 (green) and RFP-histone$2 B$ (red) were recorded by confocal microscopy (Zeiss LSM 510) together with the phase contrast. Merged image of the fluorescent labels is shown on the right. Bar, $10 \mu \mathrm{m}$
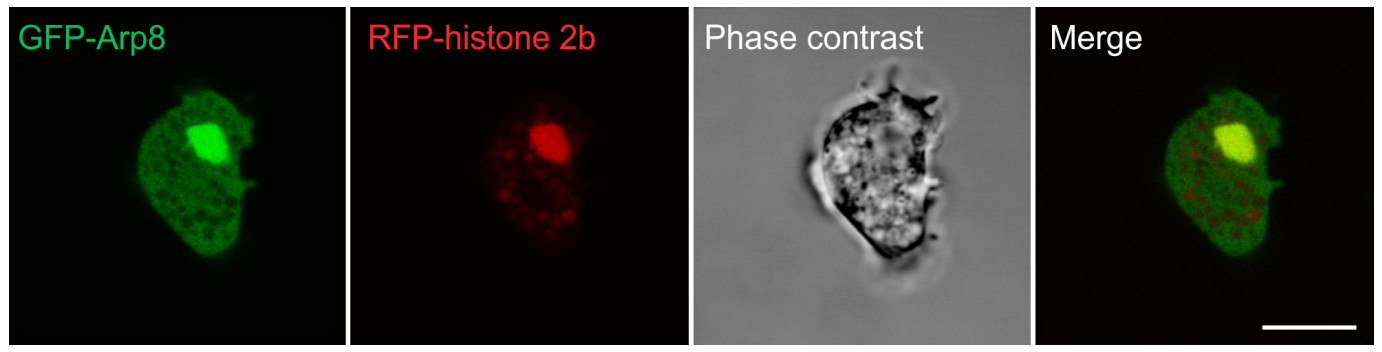

In a time-lapse movie from 1963 generated for the German Institute for Scientific Film (IWF), Günther Gerisch already documented a very detailed description of the life history of Dictyostelium (https://doi.org/10.3203/IWF/C-876\#t=01:09,03:30). The video, generated with the microscopic means available at that time, shows nicely the different stages of development including spore germination, phagocytosis, division of amoebae, cell aggregation, migration of slugs, and culmination up to the differentiation of spores.

\section{Nuclear actin}

The existence of actin in the nucleus has been debated for many years, but it is now generally accepted that actin also plays an important role in transcription by RNA polymerases I, II, and III, chromatin remodeling, DNA damage repair, and hnRNP (heterogeneous nuclear ribonucleoprotein) binding (Klages-Mundt et al., 2018). Compared to our knowledge of actin dynamics in the cytoplasm, the knowledge of the molecular basis of actin and its functions in the nucleus is still incomplete. It took many years until the presence and activities of actin and actin-related proteins (Arps) in the nucleus were clarified. Work of the last decade has revealed the role of specific Arps for chromatin remodeling like for instance the INO80 complex (Kapoor and Shen, 2014).

Studies on the $D$. discoideum actinome revealed the presence of eight different Arps (Joseph et al., 2008). Four of them (Arp $4,5,6$, and 8) localize to the nucleus (our unpublished work). Localization studies using either GFP- or Flag-tagged constructs identified these Arps inside nuclei. Consistent with data from other organisms, Arp8 together with actin and other proteins is a constituent of the chromatin-remodeling INO80 complex (our unpublished work) (Fig. 10). Despite the elucidation of Arp functions in the nucleus, the nature of other supramolecular actin structures, and thus the mechanisms of nucleation or polymerization of nuclear actin are still fragmentary.

\section{Actin assemblies induced by cellular stress: formation of actin rods in the nucleus and cytoplasm}

Actin rods (also known as actin-cofilin rods) are aggregates consisting mainly of actin and cofilin that are formed in the cytoplasm or the nucleus as a result of cellular stress. Recent work suggested that the formation of actin rods is accompanied by a reduction in cellular energy consumption, which allows a cell to temporarily survive adverse conditions. Depending on the type of stress factors, actin rods can arise either inside the nucleus or in the cytoplasm (Fig. 9B,C), and their formation is, at least to a certain degree, completely reversible. It is still unclear what exactly triggers the formation of rods, and what the underlying mechanisms of rod assembly and disassembly are. Furthermore, it is unknown to what extent nuclear and cytoplasmic rods resemble the actin rods found in spores.

Nuclear rods were first identified in Dictyostelium discoideum amoebae and in HeLa cells after treatment with high concentrations of dimethyl sulfoxide (DMSO) (Fukui, 1978, Fukui and Katsumaru, 1979, Fukui and Katsumaru, 1980, Sanger et al., 1980). Despite their description decades ago, nuclear actin rods have received little attention for many years, and have been regarded more as a morphological curiosity rather than serving a specific function. Work that focused on nuclear rods in Dictyostelium, examined the appearance, the stages of assembly, composition, stability, and dismantling of nuclear rods (IshikawaAnkerhold et al., 2017). The intranuclear rods are composed, in addition to actin and cofilin, of a distinct set of other proteins comprising actin-interacting protein 1 (Aip1), coronin (CorA), filactin, and the $34 \mathrm{kDa}$ actin-bundling protein $\mathrm{B}(\mathrm{AbpB})$. The constituent proteins are recruited in a finely tuned spatio-temporal pattern during the formation of rods. Aip1 is important for the final state of rod compaction indicating that Aip1 plays a major role in shaping the intranuclear rods. In the absence of both Aip1 and CorA, rods are not formed in the nucleus, suggesting that a sufficient supply of monomeric actin is necessary for the formation of rods (Ishikawa-Ankerhold et al., 2017).

Cytoplasmic rods (Fig. 9C) can be induced experimentally by sodium azide (Ishikawa-Ankerhold et al., 2017), but have been observed also in response to a number of different stressors that affect the cellular metabolism (our work in progress). A plausible explanation is that actin rods are formed as a protective measure to reduce the consumption of ATP of the cell to promote its survival. A current working concept suggests that protein phase separation may be used by cells to regulate protein synthesis and to ensure adaptation to a broad range of stress situations (Kroschwald and Alberti, 2017). De-mixing and the formation of quinary assemblies - in particular of actin - may provide an evolutionarily conserved mechanism for cells to adapt to and to survive extreme environmental situations.

In human cells, nuclear rods are linked to specific forms of myopathies and Huntington's disease, whereas the appearance of cytoplasmic rods is one of the early hallmarks of certain neurodegenerative diseases (Alzheimer's disease, Parkinson's disease, and ALS (amyotrophic lateral sclerosis)). However, currently little is known about specific factors that cause actin rod formation and how rod formation is modulated by physiological parameters. Dictyostelium may be used as an easily accessible system to investigate the basic principles and the physiological role of actin rod formation during different conditions of cellular stress. 


\section{Concluding remarks}

For many years, Dictyostelium discoideum has served as a valuable model to explore the actin cytoskeleton of non-muscle cells. It is without question that numerous tools now widely used in the actin cytoskeleton field have been developed using the simple model, and many of the pioneering results have promoted research in higher organisms. Despite the technical improvements and new microscopes, actin dynamics has not been studied to the same extent at all stages of development of Dictyostelium. In particular, the role of the actin cytoskeleton during the transition from a single cell to a multicellular organism and in multicellular cell movements is much less well explored.

Recent work on actin waves and macropinocytosis emphasize that research with Dictyostelium addresses cutting-edge topics. With great certainty, the use of Dictyostelium in future studies of actin cytoskeleton and cell migration research will provide further important insights that are relevant to eukaryotic cells in general.

\section{Acknowledgements}

We regret that in this review article we could only cite a limited selection of references. We sincerely thank Dr. Günther Gerisch and Mary Ecke (both Max-Planck-Institute for Biochemistry, Martinsried) for support and providing figures 3 and 5, and Supp. Movies 2 and 3, and Dr. Marion Jasnin (Max-Planck-Institute for Biochemistry, Martinsried) for providing figure 4. We thank Dr. Heike Roth (formerly LMU Munich) for help with recording two-photon videos of Dictyostelium slug stages. Furthermore, we would like to acknowledge Dominic van den Heuvel (Department of Internal Medicine I and Walter Brendel Centre of Experimental Medicine, LMU Munich), and the Deutsche Forschungsgemeinschaft for support within the framework of SFB 914 (projects Z01 and AO7E).

\section{References}

ABE, T., EARLY, A., SIEGERT, F., WEIJER, C. and WILLIAMS, J. (1994). Patterns of cell movement within the Dictyostelium slug revealed by cell type-specific, surface labeling of living cells. Cell 77: 687-699.

AIZAWA, H., SUTOH, K., TSUBUKI, S., KAWASHIMA, S., ISHII, A. and YAHARA, I. (1995). Identification, characterization, and intracellular distribution of cofilin in Dictyostelium discoideum. J Biol Chem 270: 10923-10932.

ARAI, Y., SHIBATA, T., MATSUOKA, S., SATO, M.J., YANAGIDA, T. and UEDA, M. (2010). Self-organization of the phosphatidylinositol lipids signaling system for random cell migration. Proc Natl Acad Sci USA 107: 12399-12404.

ARTEMENKO, Y., LAMPERT, T.J. and DEVREOTES, P.N. (2014). Moving towards a paradigm: common mechanisms of chemotactic signaling in Dictyostelium and mammalian leukocytes. Cell Mol Life Sci 71: 3711-3747.

BEAR, J.E., RAWLS, J.F. and SAXE, C.L., 3RD. (1998). SCAR, a WASP-related protein, isolated as a suppressor of receptor defects in late Dictyostelium development. J Cell Biol 142: 1325-1335.

BRETSCHNEIDER, T., ANDERSON, K., ECKE, M., MÜLLER-TAUBENBERGER, A., SCHROTH-DIEZ, B., ISHIKAWA-ANKERHOLD, H.C. and GERISCH, G. (2009). The three-dimensional dynamics of actin waves, a model of cytoskeletal self-organization. Biophys J 96: 2888-2900.

BRETSCHNEIDER, T., DIEZ, S., ANDERSON, K., HEUSER, J., CLARKE, M., MÜLLER-TAUBENBERGER, A., KÖHLER, J. and GERISCH, G. (2004). Dynamic actin patterns and Arp2/3 assembly at the substrate-attached surface of motile cells. Curr Biol 14: 1-10.

CAI, D., DAI, W., PRASAD, M., LUO, J., GOV, N.S. and MONTELL, D.J. (2016). Modeling and analysis of collective cell migration in an in vivo three-dimensional environment. Proc Natl Acad Sci USA 113: E2134-E2141.

CETERA, M., RAMIREZ-SAN JUAN, G.R., OAKES, P.W., LEWELLYN, L., FAIRCHILD, M.J., TANENTZAPF, G., GARDEL, M.L. and HORNE-BADOVINAC, S. (2014). Epithelial rotation promotes the global alignment of contractile actin bundles during Drosophila egg chamber elongation. Nat Commun 5: 5511
CHEN, G., ZHUCHENKO, O. and KUSPA, A. (2007). Immune-like phagocyte activity in the social amoeba. Science 317: 678-681.

CHHABRA, E.S. and HIGGS, H.N. (2007). The many faces of actin: matching assembly factors with cellular structures. Nat Cell Biol 9: 1110-1121.

CLARKE, M., SCHATTEN, G., MAZIA, D. and SPUDICH, J.A. (1975). Visualization of actin fibers associated with the cell membrane in amoebae of Dictyostelium discoideum. Proc Natl Acad Sci USA 72: 1758-1762.

CLARKE, M. and SPUDICH, J.A. (1974). Biochemical and structural studies of actomyosin-like proteins from non-muscle cells. Isolation and characterization of myosin from amoebae of Dictyostelium discoideum. J Mol Biol 86: 209-222.

CLARKE, M. and SPUDICH, J.A. (1977). Nonmuscle contractile proteins: the role of actin and myosin in cell motility and shape determination. Annu Rev Biochem 46: 797-822.

CONDEELIS, J., VAHEY, M., CARBONI, J.M., DEMEY, J. and OGIHARA, S. (1984). Properties of the 120,000- and 95,000-dalton actin-binding proteins from Dictyostelium discoideum and their possible functions in assembling the cytoplasmic matrix. J Cell Biol 99: 119s-126s.

COTTER, D.A. and RAPER, K.B. (1968). Properties of germinating spores of Dictyostelium discoideum. J Bacteriol 96: 1680-1689.

DARCY, P.K., WILCZYNSKA, Z. and FISHER, P.R. (1994). Genetic analysis of Dictyostelium slug phototaxis mutants. Genetics 137: 977-985.

DE HOSTOS, E.L., BRADTKE, B., LOTTSPEICH, F., GUGGENHEIM, R. and GERISCH, G. (1991). Coronin, an actin binding protein of Dictyostelium discoideum localized to cell surface projections, has sequence similarities to $G$ protein beta subunits. EMBO J 10: 4097-4104.

DEVREOTES, P.N. and ZIGMOND, S.H. (1988). Chemotaxis in eukaryotic cells: a focus on leukocytes and Dictyostelium. Annu Rev Cell Biol 4: 649-686.

DORMANN, D., SIEGERT, F. and WEIJER, C.J. (1996). Analysis of cell movement during the culmination phase of Dictyostelium development. Development 122 761-769.

DUNN, J.D., BOSMANI, C., BARISCH, C., RAYKOV, L., LEFRANCOIS, L.H., CARDENAL-MUNOZ, E., LOPEZ-JIMENEZ, A.T. and SOLDATI, T. (2017). Eat Prey, Live: Dictyostelium discoideum As a Model for Cell-Autonomous Defenses. Front Immunol 8: 1906.

EICHINGER, L., PACHEBAT, J.A., GLOCKNER, G., RAJANDREAM, M.A., SUCGANG, R., BERRIMAN, M., SONG, J., OLSEN, R., SZAFRANSKI, K., XU, Q. et al., (2005). The genome of the social amoeba Dictyostelium discoideum. Nature 435: 43-57.

FAIX, J., STEINMETZ, M., BOVES, H., KAMMERER, R.A., LOTTSPEICH, F., MINTERT, U., MURPHY, J., STOCK, A., AEBI, U. and GERISCH, G. (1996) Cortexillins, major determinants of cell shape and size, are actin-bundling proteins with a parallel coiled-coil tail. Cell 86: 631-642.

FECHHEIMER, M. (1987). The Dictyostelium discoideum 30,000-dalton protein is an actin filament-bundling protein that is selectively present in filopodia. $J$ Cell Biol 104: 1539-1551.

FECHHEIMER, M. and TAYLOR, D.L. (1984). Isolation and characterization of a 30,000-dalton calcium-sensitive actin cross-linking protein from Dictyostelium discoideum. J Biol Chem 259: 4514-4520.

FISCHER, M., HAASE, I., SIMMETH, E., GERISCH, G. and MÜLLER-TAUBENBERGER, A. (2004). A brilliant monomeric red fluorescent protein to visualize cytoskeleton dynamics in Dictyostelium. FEBS Lett 577: 227-232.

FREJ, A.D., OTTO, G.P. and WILLIAMS, R.S. (2017). Tipping the scales: Lessons from simple model systems on inositol imbalance in neurological disorders. Eur J Cell Biol 96: 154-163.

FUKUI, Y. (1978). Intranuclear actin bundles induced by dimethyl sulfoxide in interphase nucleus of Dictyostelium. J Cell Biol 76: 146-157.

FUKUI, Y. and KATSUMARU, H. (1979). Nuclear actin bundles in Amoeba, Dictyostelium and human HeLa cells induced by dimethyl sulfoxide. Exp Cell Res 120: $451-455$

FUKUI, Y. and KATSUMARU, H. (1980). Dynamics of nuclear actin bundle induction by dimethyl sulfoxide and factors affecting its development. J Cell Bio/84: 131-140.

GERISCH, G. (1982). Chemotaxis in Dictyostelium. Annu Rev Physiol 44: 535-552.

GERISCH, G. and MÜLLER-TAUBENBERGER, A. (2003). GFP-fusion proteins as fluorescent reporters to study organelle and cytoskeleton dynamics in chemotaxis and phagocytosis. Methods Enzymol 361: 320-337. 
GERISCH, G., SCHROTH-DIEZ, B., MÜLLER-TAUBENBERGER, A. and ECKE, M. (2012). PIP3 waves and PTEN dynamics in the emergence of cell polarity. Biophys J 103: 1170-1178.

HAAS, P. and GILMOUR, D. (2006). Chemokine signaling mediates self-organizing tissue migration in the zebrafish lateral line. Dev Cell 10: 673-680.

HARTMANN, H., NOEGEL, A.A., ECKERSKORN, C., RAPP, S. and SCHLEICHER, M. (1989). Ca2+-independent F-actin capping proteins. Cap 32/34, a capping protein from Dictyostelium discoideum, does not share sequence homologies with known actin-binding proteins. J Biol Chem 264: 12639-12647.

HASHIMURA, H., MORIMOTO, Y.V., YASUI, M. and UEDA, M. (2019). Collective cell migration of Dictyostelium without cAMP oscillations at multicellular stages. Commun Biol 2: 34

HAUGWITZ, M., NOEGEL, A.A., RIEGER, D., LOTTSPEICH, F. and SCHLEICHER, M. (1991). Dictyostelium discoideum contains two profilin isoforms that differ in structure and function. J Cell Sci 100: 481-489.

INAGAKI, N. and KATSUNO, H. (2017). Actin Waves: Origin of Cell Polarization and Migration? Trends Cell Biol 27: 515-526.

INSALL, R. (2013). The interaction between pseudopods and extracellular signalling during chemotaxis and directed migration. Curr Opin Cell Biol 25: 526-531.

INSALL, R., MÜLLER-TAUBENBERGER, A., MACHESKY, L., KÖHLER, J., SIMMETH, E., ATKINSON, S.J., WEBER, I. and GERISCH, G. (2001). Dynamics of the Dictyostelium Arp2/3 complex in endocytosis, cytokinesis, and chemotaxis. Cell Motil Cytoskeleton 50: 115-128.

ISHIKAWA-ANKERHOLD, H.C., DASZKIEWICZ, W., SCHLEICHER, M. and MÜLLER-TAUBENBERGER, A. (2017). Actin-Interacting Protein 1 Contributes to Intranuclear Rod Assembly in Dictyostelium discoideum. Sci Rep 7: 40310.

JASNIN, M., BECK, F., ECKE, M., MARTINEZ-SACHEZ, A., BAUMEISTER, W. and GERISCH, G. (2019). The architecture of traveling waves revealed by cryo-electron tomography. Structure 26: 1211-1223.

JASNIN, M., ECKE, M., BAUMEISTER, W. and GERISCH, G. (2016). Actin Organization in Cells Responding to a Perforated Surface, Revealed by Live Imaging and Cryo-Electron Tomography. Structure 24: 1031-1043.

JOSEPH, J.M., FEY, P., RAMALINGAM, N., LIU, X.I., ROHLFS, M., NOEGEL, A.A., MÜLLER-TAUBENBERGER, A., GLÖCKNER, G. and SCHLEICHER, M. (2008). The actinome of Dictyostelium discoideum in comparison to actins and actin-related proteins from other organisms. PLoS One 3: e2654.

KAPOOR, P. and SHEN, X. (2014). Mechanisms of nuclear actin in chromatinremodeling complexes. Trends Cell Biol 24: 238-246.

KAY, R.R. (1992). Cell differentiation and patterning in Dictyostelium. Curr Opin Cell Biol 4: 934-938.

KAY, R.R., LANGRIDGE, P., TRAYNOR, D. and HOELLER, O. (2008). Changing directions in the study of chemotaxis. Nat Rev Mol Cell Biol 9: 455-463.

KLAGES-MUNDT, N.L., KUMAR, A., ZHANG, Y., KAPOOR, P. and SHEN, X. (2018). The Nature of Actin-Family Proteins in Chromatin-Modifying Complexes. Front Genet 9: 398

KOENIG, M., MONACO, A.P. and KUNKEL, L.M. (1988). The complete sequence of dystrophin predicts a rod-shaped cytoskeletal protein. Cell 53: 219-228.

KONIJN, T.M., CHANG, Y.Y. and BONNER, J.T. (1969). Synthesis of cyclic AMP in Dictyostelium discoideum and Polysphondylium pallidum. Nature224:1211-1212.

KREITMEIER, M., GERISCH, G., HEIZER, C. and MÜLLER-TAUBENBERGER, A. (1995). A talin homologue of Dictyostelium rapidly assembles at the leading edge of cells in response to chemoattractant. J Cell Biol 129: 179-188.

KROSCHWALD, S. and ALBERTI, S. (2017). Gel or Die: Phase Separation as a Survival Strategy. Cell 168: 947-948.

LÄMMERMANN, T., BADER, B.L., MONKLEY, S.J., WORBS, T., WEDLICHSÖLDNER, R., HIRSCH, K., KELLER, M., FORSTER, R., CRITCHLEY, D.R., FÄSSLER, R. et al., (2008). Rapid leukocyte migration by integrin-independent flowing and squeezing. Nature 453: 51-55.

LANGE, M., PRASSLER, J., ECKE, M., MÜLLER-TAUBENBERGER, A. and GERISCH, G. (2016). Local Ras activation, PTEN pattern, and global actin flow in the chemotactic responses of oversized cells. J Cell Sci 129: 3462-3472.

LAZARIDES, E. and WEBER, K. (1974). Actin antibody: the specific visualization of actin filaments in non-muscle cells. Proc Natl Acad Sci USA 71: 2268-2272.

LEMIEUX, M.G., JANZEN, D., HWANG, R., ROLDAN, J., JARCHUM, I. and KNECHT, D.A. (2014). Visualization of the actin cytoskeleton: different F-actin-binding probes tell different stories. Cytoskeleton (Hoboken) 71: 157-169.

LITSCHKO, C., BRUHMANN, S., CSISZAR, A., STEPHAN, T., DIMCHEV, V., DAMIANO-GUERCIO, J., JUNEMANN, A., KORBER, S., WINTERHOFF, M., NORDHOLZ, B. et al., (2019). Functional integrity of the contractile actin cortex is safeguarded by multiple Diaphanous-related formins. Proc Natl Acad Sci USA 116: 3594-3603.

MACHESKY, L.M., ATKINSON, S.J., AMPE, C., VANDEKERCKHOVE, J. and POLLARD, T.D. (1994). Purification of a cortical complex containing two unconventional actins from Acanthamoeba by affinity chromatography on profilin-agarose. J Cell Biol 127: 107-115.

MACHESKY, L.M., MULLINS, R.D., HIGGS, H.N., KAISER, D.A., BLANCHOIN, L., MAY, R.C., HALL, M.E. and POLLARD, T.D. (1999). Scar, a WASp-related protein, activates nucleation of actin filaments by the Arp2/3 complex. Proc Natl Acad Sci USA 96: 3739-3744.

MANAHAN, C.L., IGLESIAS, P.A., LONG, Y. and DEVREOTES, P.N. (2004). Chemoattractant signaling in dictyostelium discoideum. Annu Rev Cell Dev Biol 20: 223-253.

MANIAK, M., RAUCHENBERGER, R., ALBRECHT, R., MURPHY, J. and GERISCH, G. (1995). Coronin involved in phagocytosis: dynamics of particle-induced relocalization visualized by a green fluorescent protein Tag. Cell 83: 915-924.

MEDALIA, O., BECK, M., ECKE, M., WEBER, I., NEUJAHR, R., BAUMEISTER, W. and GERISCH, G. (2007). Organization of actin networks in intact filopodia. Curr Biol 17: 79-84.

MEDALIA, O., WEBER, I., FRANGAKIS, A.S., NICASTRO, D., GERISCH, G. and BAUMEISTER, W. (2002). Macromolecular architecture in eukaryotic cells visualized by cryoelectron tomography. Science 298: 1209-1213.

MÜLLER-TAUBENBERGER, A. (2006). Application of fluorescent protein tags as reporters in live-cell imaging studies. Methods Mol Biol 346: 229-246.

MÜLLER-TAUBENBERGER, A. and ANDERSON, K.I. (2007). Recent advances using green and red fluorescent protein variants. Appl Microbiol Biotechnol 77: 1-12.

MÜLLER-TAUBENBERGER, A., BRETSCHNEIDER, T., FAIX, J., KONZOK, A., SIMMETH, E. and WEBER, I. (2002). Differential localization of the Dictyostelium kinase DPAKa during cytokinesis and cell migration. J Muscle Res Cell Motil 23: 751-763.

MÜLLER-TAUBENBERGER, A. and ISHIKAWA-ANKERHOLD, H.C. (2013). Fluorescent reporters and methods to analyze fluorescent signals. Methods Mol Biol 983: 93-112.

MÜLLER-TAUBENBERGER, A., KORTHOLT, A. and EICHINGER, L. (2013). Simple system - substantial share: the use of Dictyostelium in cell biology and molecular medicine. Eur J Cell Biol 92: 45-53.

NACHMIAS, V.T. and INGRAM, W.C. (1970). Actomyosin from Physarum polycephalum: electron microscopy of myosin-enriched preparations. Science 170: 743-745

NOEGEL, A.A., RAPP, S., LOTTSPEICH, F., SCHLEICHER, M. and STEWART, M. (1989). The Dictyostelium gelation factor shares a putative actin binding site with alpha-actinins and dystrophin and also has a rod domain containing six 100-residue motifs that appear to have a cross-beta conformation. $J$ Cell Biol 109: 607-618.

NOEGEL, A.A. and SCHLEICHER, M. (2000). The actin cytoskeleton of Dictyostelium: a story told by mutants. J Cell Sci 113: 759-766.

OLSON, H.M. and NECHIPORUK, A.V. (2018). Using Zebrafish to Study Collective Cell Migration in Development and Disease. Front Cell Dev Biol 6: 83

POLLARD, T.D. and BORISY, G.G. (2003). Cellular motility driven by assembly and disassembly of actin filaments. Cell 112: 453-465.

POLLARD, T.D., SHELTON, E., WEIHING, R.R. and KORN, E.D. (1970). Ultrastructural characterization of F-actin isolated from Acanthamoeba castellanii and identification of cytoplasmic filaments as F-actin by reaction with rabbit heavy meromyosin. $J$ Mol Biol 50: 91-97.

POLLITT, A.Y. and INSALL, R.H. (2009). WASP and SCAR/WAVE proteins: the drivers of actin assembly. J Cell Sci 122: 2575-2578.

RIEDL, J., CREVENNA, A.H., KESSENBROCK, K., YU, J.H., NEUKIRCHEN, D., BISTA, M., BRADKE, F., JENNE, D., HOLAK, T.A., WERB, Z. et al., (2008). Lifeact: a versatile marker to visualize F-actin. Nat Methods 5: 605-607.

RIVERO, F., MURAMOTO, T., MEYER, A.K., URUSHIHARA, H., UYEDA, T.Q. and KITAYAMA, C. (2005). A comparative sequence analysis reveals a common 
GBD/FH3-FH1-FH2-DAD architecture in formins from Dictyostelium, fungi and metazoa. BMC Genomics 6: 28.

ROTH, H., SAMEREIER, M., TROMMLER, G., NOEGEL, A.A., SCHLEICHER, M. and MÜLLER-TAUBENBERGER, A. (2015). Balanced cortical stiffness is important for efficient migration of Dictyostelium cells in confined environments. Biochem Biophys Res Commun 467: 730-735.

SAMESHIMA, M., CHIJIIWA, Y., KISHI, Y. and HASHIMOTO, Y. (1994). Novel actin rods appeared in spores of Dictyostelium discoideum. Cell Struct Funct 19: 189-194.

SAMESHIMA, M., KISHI, Y., OSUMI, M., MAHADEO, D. and COTTER, D.A. (2000). Novel actin cytoskeleton: actin tubules. Cell Struct Funct 25: 291-295.

SAMESHIMA, M., KISHI, Y., OSUMI, M., MINAMIKAWA-TACHINO, R., MAHADEO, D. and COTTER, D.A. (2001). The formation of actin rods composed of actin tubules in Dictyostelium discoideum spores. J Struct Biol 136: 7-19.

SANGER, J.W., SANGER, J.M., KREIS, T.E. and JOCKUSCH, B.M. (1980). Reversible translocation of cytoplasmic actin into the nucleus caused by dimethyl sulfoxide. Proc Natl Acad Sci USA 77: 5268-5272.

SCHEEL, J., ZIEGELBAUER, K., KUPKE, T., HUMBEL, B.M., NOEGEL, A.A., GERISCH, G. and SCHLEICHER, M. (1989). Hisactophilin, a histidine-rich actinbinding protein from Dictyostelium discoideum. J Biol Chem 264: 2832-2839.

SCHIRENBECK, A., BRETSCHNEIDER, T., ARASADA, R., SCHLEICHER, M. and FAIX, J. (2005). The Diaphanous-related formin dDia2 is required for the formation and maintenance of filopodia. Nat Cell Biol 7: 619-625.

SCHROTH-DIEZ, B., GERWIG, S., ECKE, M., HEGERL, R., DIEZ, S. and GER$\mathrm{ISCH}, \mathrm{G}$. (2009). Propagating waves separate two states of actin organization in living cells. HFSP J 3: 412-427.

SIEGERT, F. and WEIJER, C.J. (1995). Spiral and concentric waves organize multicellular Dictyostelium mounds. Curr Biol 5: 937-943.

SPUDICH, J.A. (1974). Biochemical and structural studies of actomyosin-like proteins from non-muscle cells. II. Purification, properties, and membrane association of actin from amoebae of Dictyostelium discoideum. J Biol Chem 249: 6013-6020.

TYSON, R.A., ZATULOVSKIY, E., KAY, R.R. and BRETSCHNEIDER, T. (2014). How blebs and pseudopods cooperate during chemotaxis. Proc Natl Acad Sci USA 111: 11703-11708.

VELTMAN, D.M. and INSALL, R.H. (2010). WASP family proteins: their evolution and its physiological implications. Mol Biol Cell 21: 2880-2893.

VICKER, M.G. (2002). F-actin assembly in Dictyostelium cell locomotion and shape oscillations propagates as a self-organized reaction-diffusion wave. FEBS Lett 510: 5-9.

WESTPHAL, M., JUNGBLUTH, A., HEIDECKER, M., MUHLBAUER, B., HEIZER, C., SCHWARTZ, J.M., MARRIOTT, G. and GERISCH, G. (1997). Microfilament dynamics during cell movement and chemotaxis monitored using a GFP-actin fusion protein. Curr Biol 7: 176-183.

WITKE, W., SCHLEICHER, M., LOTTSPEICH, F. and NOEGEL, A. (1986). Studies on the transcription, translation, and structure of alpha-actinin in Dictyostelium discoideum. J Cell Biol 103: 969-975.

WOOLLEY, D.E. (1972). An actin-like protein from amoebae of Dictyostelium discoideum. Arch Biochem Biophys 150: 519-530.

YAMAMOTO, K., PARDEE, J.D., REIDLER, J., STRYER, L. and SPUDICH, J.A (1982). Mechanism of interaction of Dictyostelium severin with actin filaments. J Cell Biol 95: 711-719.

YOSHIDA, K. and SOLDATI, T. (2006). Dissection of amoeboid movement into two mechanically distinct modes. J Cell Sci 119: 3833-3844.

ZATULOVSKIY, E., TYSON, R., BRETSCHNEIDER, T. and KAY, R.R. (2014). Blebdriven chemotaxis of Dictyostelium cells. J Cell Biol 204: 1027-1044.

ZHANG, X., ZHUCHENKO, O., KUSPA, A. and SOLDATI, T. (2016). Social amoebae trap and kill bacteria by casting DNA nets. Nat Commun 7: 10938 


\section{Further Related Reading, published previously in the Int. J. Dev. Biol.}

Bimodal distribution of motility and cell fate in Dictyostelium discoideum

Pavana Goury-Sistla, Vidyanand Nanjundiah and Gopal Pande

Int. J. Dev. Biol. (2012) 56: 263-272

https://doi.org/10.1387/ijdb.113384ps

Analysis of a homologue of the adducin head gene which is a potential target for the Dictyostelium STAT protein Dd-STATa Ryota Aoshima, Rieko Hiraoka, Nao Shimada and Takefumi Kawata

Int. J. Dev. Biol. (2006) 50: 523-532

https://doi.org/10.1387/ijdb.052113ra

Cell-cell signaling and adhesion in phagocytosis and early development of Dictyostelium E Bracco, B Pergolizzi, B Peracino, E Ponte, A Balbo, A Mai, A Ceccarelli and S Bozzaro Int. J. Dev. Biol. (2000) 44: 733-742

http://www.intjdevbiol.com/web/paper/11061438

Deletion of etoposide-induced $2.4 \mathrm{~kb}$ transcript (ei24) reduced cell proliferation and aggregate-size in Dictyostelium discoideum

Neha Gupta and Shweta Saran

Int. J. Dev. Biol. (2018) 62: 273-283

https://doi.org/10.1387/ijdb.170327ss

An orthologue of the Myelin-gene Regulatory Transcription Factor regulates Dictyostelium prestalk differentiation

Hiroshi Senoo, Hong-Yu Wang, Tsuyoshi Araki, Jeffrey G. Williams and Masashi Fukuzawa Int. J. Dev. Biol. (2012) 56: 325-334

https://doi.org/10.1387/ijdb.120030jw

Bimodal distribution of motility and cell fate in Dictyostelium discoideum

Pavana Goury-Sistla, Vidyanand Nanjundiah and Gopal Pande

Int. J. Dev. Biol. (2012) 56: 263-272

https://doi.org/10.1387/ijdb.113384ps

ASET/MYND chromatin re-modelling protein regulates Dictyostelium prespore patterning Beatriz Nuñez-Corcuera, Joanna Birch and Jeffrey G. Williams Int. J. Dev. Biol. (2011) 55: 205-208

https://doi.org/10.1387/ijdb.113309bn
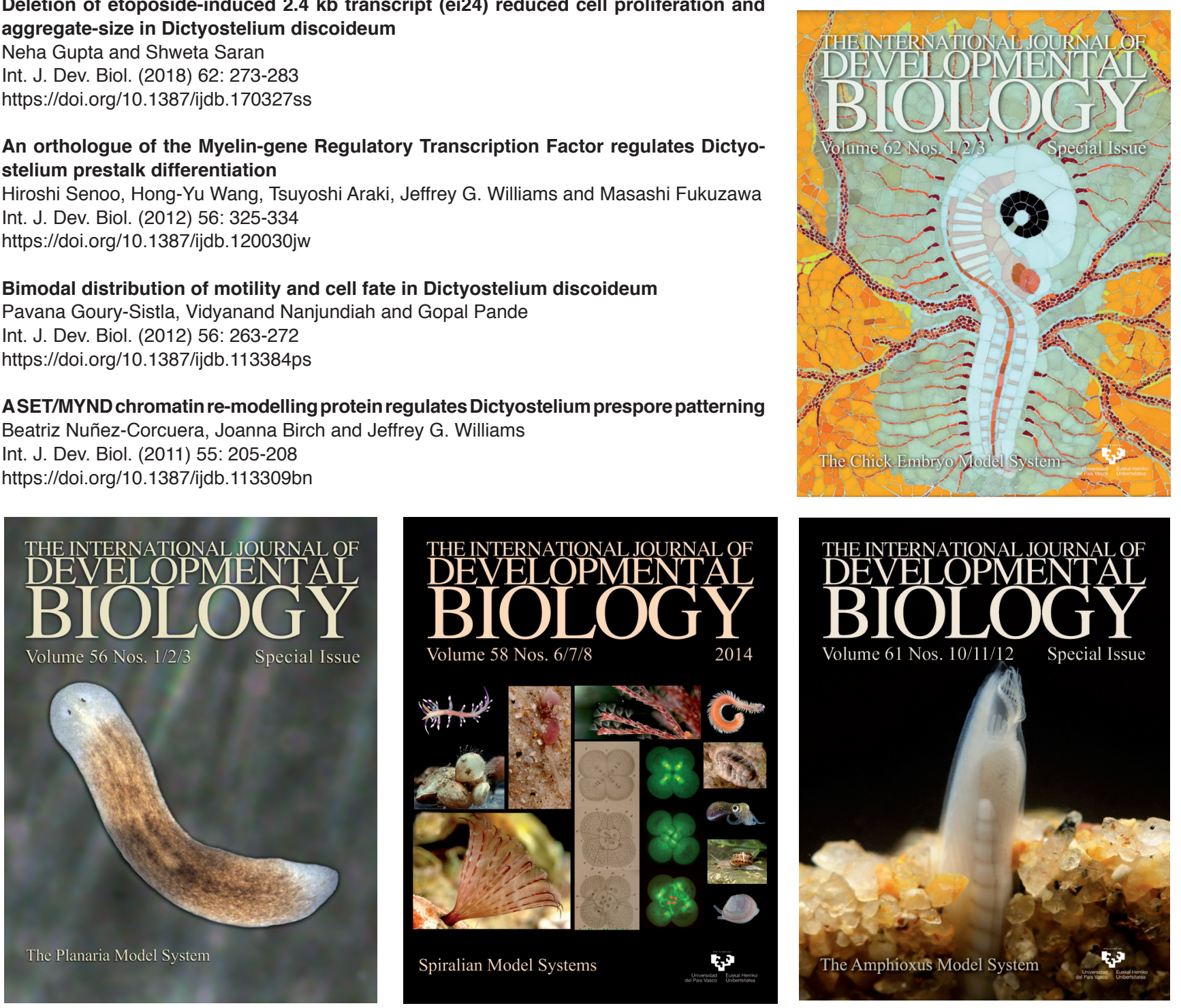